\title{
PENGARUH KEDISIPLINAN KERJA TERHADAP PRODUKTIVITAS KERJA KARYAWAN PADA PT. SBA WOOD INDUSTRI PALEMBANG
}

\author{
Yuli Anita \\ Dosen Tetap Fakultas Ekonomi Universitas Palembang
}

\begin{abstract}
ABSTRAK
Penelitian ini menguji Pengaruh Kedisiplinan Kerja terhadap Produktvitas Kerja Karyawan Pada PT. SBA Wood Industri Palembang. Tujuan dari penelitian ini adalah Untuk Mengetahui Kedisiplinan Kerja mempunyai pengaruh secara parsial dan parsial terhadap Produktvitas Kerja Karyawan Pada PT. SBA Wood Industri Palembang

Penelitian ini dilaksanakan di Penelitian ini dilakukan Pada PT. SBA Wood Industri Palembang yang beralamat Jl. R.Soekamto Komplek Ruko PTC Blok I No.63-66 Palembang. Pada penelitian ini, populasi adalah pekerja dan staff yang bekerja pada PT. SBA Wood Industri Palembang sebanyak 350 orang. penentuan jumlah sampel pada penelitian ini adalah menggunakan teknik probabilitas dengan cara random sampling (Metode sampel acak sederhana), yaitu dengan metode pemilihan sampel di mana setiap anggota populasi mempunyai peluang yang sama untuk dipilih menjadi anggota sampel. Untuk menentukan jumlah sampel yang diambil pada penelitian ini menggunakan rumus slovin sebesar 77 orang.

Hasil yang didapat dari analisis regresi dengan mengunakan alat SPSS versi 22 menunjukkan bahwa ada pengaruh kedisiplinan kerja terhadap produktivitas kerja karyawan pada PT. SBA WOOD Industri Palembang.
\end{abstract}

Kata Kunci: Disiplin Kerja, Produktivitas Kerja

\section{LATAR BELAKANG}

\subsection{Latar Belakang Masalah}

Disiplin merupakan bentuk pelatihan yang menegakkan peraturanperaturan organisasi. Disiplin kerja pegawai merupakan hal yang penting karena dengan ditegakkannya disiplin, pegawai dapat melakukan pekerjaanya sesuai dengan prosedur dan aturan yang telah di tetapkan untuk mencapai tujuan. Apabila peraturan telah di patuhi, maka berarti pula para pegawai tersebut memberikan dukungan yang positif terhadap organisasi dalam melaksanakan program-program yang telah ditetapkan sehingga akan lebih mudah dalam mencapai tujuan organisasi. Disiplin yang baik mencerminkan besarnya tanggung jawab seseorang terhadap tugas-tugas yang diberikan kepadanya, hal ini mendorong gairah kerja, semangat kerja, dan terwujudnya tujuan organisasi. Disiplin yang baik dari pegawai juga akan menunjukkan bahwa organisasi dapat memelihara serta menjaga loyalitas dan kualitas pegawainya, dari disiplin juga dapat diketahui nilai kinerja dari para pegawainya.Disiplin kerja merupakan bentuk pengendalian diri pegawai dan pelaksanaan yang teratur serta menunjukan tingkat kesungguhan tim kerja di dalam sebuah instansi ataupun organisasi. Disiplin kerja yang baik menunujukan besarnya rasa tanggung jawab seseorang terhadap tugas-tugas yang diberikan kepadanya. Penerapan disiplin kerja bagi pegawai bertujuan untuk mendorong pegawai agar mengikuti berbagai standar ataupun aturan yang berlaku pada perusahaan tersebut, sehingga penyelewengan-penyelewengan kerja dapat di atasi. Untuk itu, seorang 
pemimpin kiranya sedapat mungkin menyelenggarakan tindakan indisipliner agar pegawai dapat mengemban tugasnya sesuai dengan prosedur yang ada. Dengan cara ini pegawai akan menjalankan disiplin kerja mereka bukan semata-mata karena dipaksa tetapi sudah menjadi suatu keharusan. Jalan keluar yang dilakukan oleh fungsinya terhadap kinerja pegawai adalah kepemimpinan, selain kepemimpinan ada juga faktor lain yang harus di perhatikan dalam mencapai kinerja organisasi yang baik yaitu disiplin kerja pegawai.

Disiplin merupakan bentuk pelatihan yang menegakkan peraturan yang ada di suatu organisasi.Hasil dari kinerja pegawai merupakan pekerjaan yang di lakukan sesuai dengan prosedur dan peraturan yang telah di tetapkan untuk mencapai tujuan, sehingga para pegawai tersebut memberikan dukungan yang positif terhadap organisasi dalam melaksanakan program-program yang telah di tetapkan sehingga akan lebih mudah dalam mencapai tujuan organisasi. Disiplin yang baik dari pegawai juga akan menunjukkan bahwa organisasi dapat memelihara serta menjaga loyalitas dan kualitas pegawainya, dari disiplin juga dapat di ketahui nilai kinerja dari para pegawainya. Kinerja pegawai yang rendah akan menjadi sutau permasalahan bagi sebuah organisasi atau lembaga, karena kinerja yang dihasilkan pegawai tidak sesuai dengan yang diharapkan oleh PT. SBA Wood Industri Palembang. Untuk memberikan gambaran tentang kinerja pegawai, berikut ini adalah beberapa penjelasan yang berkaitan dengan kinerja pegawai di PT.SBA Wood Industri Palembang Dikatakan bahwa kinerja merupakan:

1. sesuatu yang dicapai

2. prestasi yang diperlihatkan

3. Kemampuan kerja.

Sehingga dapat disimpulkan bahwa kinerja merupakan hasil kerja yang dihasilkan oleh pegawai atau karyawan dalam melakukan tugas dan tanggung jawabnya.

Berdasarkan lingkup fenomena pola kerja pegawai yang ada di atas, disiplin terutama di tinjau dari perspektif organisasi, dapat di rumuskan sebagai ketaatan setiap anggota organisasi terhadap semua aturan yang berlaku di dalam organisasi tersebut, yang terwujud melalui sikap, perilaku dan perbuatan yang baik sehingga tercipta keteraturan, keharmonisan, tidak ada perselisihan, serta keadaan baik lainnya. PT. SBA Wood Industri merupakan salah satu perusahaan yang bergerak di bidang Hutan Tanaman Industri (HTI). Dimana tugas pokoknya adalah pengelolaan sumber daya hutan sebagai ekosistem secara efisien dan profesional guna menjamin kelestarian fungsi produksi, ekologi dan sosial dalam membangun hutan tanaman.

Dalam melaksanakan tugas-tugas perusahaan di butuhkan adanya disiplin kerja yang maksimal. Berdasarkan fenomena dilapangan peneliti mendapatkan masaalah seperti, masih ada pegawai yang kurang disiplin dalam menjalankan tugas pokoknya, seperti tidak tepat waktu dalam mengerjakan tugas yang diemban, minimnya rapat evaluasi atas hasil-hasil kerja dalam periode waktu tertentu pada setiap unit kerja, terdapat sebagian pegawai menunda-nunda pekerjaan yang menjadi tanggung jawabnya. Disamping itu juga ada sebagian pegawai yang kurang mentaati aturan jam kantor.

Adanya pegawai yang dating tidak tepat waktu, mengunakan waktu istirahat melebihi jam yang telah ditetapkan. Bahkan ada yang pulang sebelum jam kerja berakhir. Produktivitas merupakan suatu hasil kerja dari seorang karyawan. Hasil kerja ini merupakan suatu proses bekerja dari seseorang dalam pekerjaanya. Sebagaimana diketahui bahwa setiap organisasi, baik yang bergerak dalam bidang bisnis maupun non bisnis memanfaatkan sumber daya yang terbatas untuk memperoleh hasil sesuai yang 
direncanakan. Sumber daya yang dikelola adalah pekerja atau karyawan sebagai sumber daya manusia, mesin, material, uang, dan informasi. Faktor kerja sebagai sumber manusia merupakan faktor yang terpenting faktor-faktor produksi lain dalam organisasi karena sumber daya manusia merencanakan, melaksanakan, dan mengendalikan setiap kegiatan organisasi untuk mencapai tujuan. Para pekerja atau karyawan tidak dapat dan tidak boleh di samakan dengan alat atau mesin pabrik karena para pekerja adalah manusia yang mempunyai kepribadian yang beraneka ragam yang dapat mempengaruhi produktivitas kerja. Kenyataan sering ditemukan bahwa dalam keadaan syarat-syarat kerja sudah terpenuhi, produktivitas kerja karyawan dirasakan masih terlalu rendah. Bahkan selalu mencari alasan bahwa produktivitas kerja karyawan yang rendah karena terbatasnya sumber daya yang dimiliki perusahaan atau ketidakpuasan karyawan. Sebagian besar orang menafsirkan atau memandang bahwa keadaan yang tidak memuaskan disebabkan oleh upah atau gaji yang rendah. Pandangan itu memang benar dan tidak dapat dibantah bahwa upah dan kondisi kerja besar pengaruhnya terhadap produktivitas kerja, tetapi semangat kerja, kompensasi dan disiplin kerja jauh lebih besar peranan dan pengaruhnya terhadap produktivitas kerja karyawan.

Menurut Panggabean (2012), ada dua cara untuk mendefinisikan semangat kerja, (1). kondisi dari sebuah kelompok dimana ada tujuan yang jelas dan tetap yang dirasakan menjadi penting dan terpadu dengan tujuan individu. (2). Semangat kerja merujuk kepada adanya kebersamaan. Hal ini merupakan rasa pemahaman dengan perhatian terhadap unsur-unsur dari pekerjaan seseorang, kondisi kerja, pimpinan, dan perusahaan. Unsur penting dari semangat kerja adalah adanya keinginan untuk mencapai tujuan dari sebuah kelompok tertentu. Sebuah contoh yang tepat dari semangat kerja adalah adanya kepahlawanan dalam perang. Ketika seseorang menyerahkan nyawanya, maka tubuhnya dapat mempunyai sebuah kesempatan atau dapat mencapai sebuah tujuan.Kompensasi adalah semua pendapatan yang berbentuk uang, barang langsung atau tidak langsung yang diterima karyawan sebagai imbalan atas jasa yang diberikan kepada perusahaan. Menurut (Hasibuan, 2012). Besarnya kompensasi harus diusahakan sedemikian rupa sehinggamampu mengikat karyawan. Hal ini adalah sangat penting sebab bila kompensasi yang diberikan kepada karyawan terlalu kecil bila dibandingkan perusahaan lain pada umumnya, bila ada kesempatan menimbulkan kecenderungan pindahnya mereka ke perusahaan lain. Hal ini harus diperhatikan terutama bagi karyawan yang penting sebab mereka ini pada umumnya telah diberikan pelatihan dengan biaya cukup besar. Menurut.(Nitisemito, 2016). Disiplin pada hakikatnya adalah kemampuan untuk mengendalikan diri dalam bentuk tidak melakukan sesuatu tindakan yang tidak sesuai dan bertentangan dengan sesuatu yang telah ditetapkan dan melakukan sesuatu yang telah ditetapkan. Disiplin kerja merupakan kemampuan seseorang untuk secara taratur, tekun secara terusmenerus dan bekerja sesuai dengan aturanaturan yang sudah ditetapkan.

PT. Sebangun Bumi Andalas (SBA) Wood Industries (Palembang Partner Sinarmas Forestry) merupakan perusahaan yang bergerak di bidang Hutan Tanaman Industri (HTI). Salah satu visi perusahaan adalah terwujudnya pengelolaan sumber daya hutan sebagai ekosistem secara efisien dan profesional guna menjamin kelestarianfungsi produksi, ekologi dan sosial dalam membangun hutan tanaman.

Misinya adalah Menyelenggarakan kegiatan pengusahaan hutan tanaman berdasarkan prinsip-prinsip pengelolaan 
hutan secara lestari melalui kegiatan sebagai berikut :

- Membangun dan mengelola hutan tanaman dengan tujuan produksi kayu secara optimal dengan menerapkan teknologi tepat guna dan dengan dukungan manajerial dan sumber daya manusia yang handal dan profesional;

- Berupaya mempertahankan mutu lingkungan hidup melalui pengelolaan sumber daya hutan secara benar

Melakukan perlindungan dan konservasi keanekaragaman hayati beserta ekosistemnya pada areal yang telah ditetapkan dalam tata ruang

- Mengelola sumberdaya hutan sebagai ekosistem secara partisipatif bersama stakeholder.

- Berupaya meningkatkan ekonomi masyarakat setempat melalui peran serta masyarakat secara langsung maupun tidak langsung

Adapun peraturan-peraturan yang tidak boleh dilanggar dalam perusahaan yaitu sebagai berikut :

- Tidak boleh menyebarkan rahasia perusahaan

- $\quad$ Tidak boleh merokok di saat sedang bekerja / di ruang kerja

- Tidak boleh berdagang di tempat kerja

- Harus cuci tangan dan kaki sebelum bekerja Perusahaan PT. SBA Wood Industri Palembang. ini menerapkan sistem kompensasi dengan cara, (1) Jasa produksi berupa honor di berikan setiap bulan, untuk para karyawankaryawan dalam bidang produksi. (2) pada saat menjelang idul fitri biasanya pesanan teh bisa melonjak, oleh karena itu perusahaan pada saaat menjelang idul fitri menetapkan system lembur bagi karyawan bagian produksi. Sebagai imbalannya perusahaan akan mengasih gaji $2 \mathrm{x}$ lipat dari gaji biasa. Perbedaan penelitian ini dengan penelitian sebelumnya adalah adannya penambahan variabel.

Pada penelitian sebelumnya dilakukan penelitian diUniversitas Udayana, Denpasar. Sedangkan penelitin yang sekarang melakukan penelitian Pada PT. SBA Wood Industri Palembang. Selanjutnya mengenai variabel, pada penelitian sebelumnya hanya menggunakan variabel semangat kerja pada variabel independent dan variabel produktivtas pada varibel dependent. Dalam penelitian ini menambahkan variabel disiplin kerja pada varibel independent, dan variabel dependentnya tetap mengunakan variabel produktivitas kerja karyawan. Berdasarkan latar belakang diatas, penelitian ini mengambil judul "Pengaruh Kedisiplinan Kerja Terhadap Produktvitas Kerja Karyawan Pada PT. SBA Wood Industri Palembang”.

\subsection{Perumusan Masalah}

Berdasarkan uraian diatas, maka perumusan masalah dalam penelitian ini adalah Berdasarkan pada latar belakang penelitian yang telah diuraikan di atas maka permasalahan diatas dapat diidentifikasikan sebagai berikut :

1.2.1 Apakah Kedisiplinan Kerja mempunyai pengaruh secara parsial terhadap Produktvitas Kerja Karyawan Pada PT. SBA Wood Industri Palembang?

1.2.2 Apakah Kedisiplinan Kerja mempunyai pengaruh secara simultan terhadap Produktvitas Kerja Karyawan Pada PT. SBA Wood Industri Palembang?

\subsection{Tujuan penelitian}

Adapun tujuan penelitian. yang dilakukan oleh penulis sebagai berikut :

1.3.1 Untuk Mengetahui Kedisiplinan Kerja mempunyai pengaruh secara parsial terhadap Produktvitas Kerja Karyawan Pada PT. SBA Wood Industri Palembang? 
1.3.2 Untuk Mengetahui Kedisiplinan Kerja mempunyai pengaruh secara simultan terhadap Produktvitas Kerja Karyawan Pada PT. SBA Wood Industri Palembang?

\subsection{MANFAAT PENELITIAN}

\subsubsection{Bagi Perusahaan}

Penelitian ini dapat memberikan masukan yang mungkin bermanfaat bagi perusahaan mengenai pengaruh disiplin kerja terhadap produktvitas kerja karyawan pada PT. SBA Wood Industri Palembang?

\subsubsection{Bagi Peneliti}

Penelitian ini merupakan suatu kesempatan bagi penulis untuk menerapkan ilmu Pengetahuan yang telah diperoleh selama menjalani perkuliahan dan memperluas pengetahuan penulis dalam bidang Manajemen Sumber Daya Manusia pada umumnya dan kinerja karyawan khususnya.

\subsubsection{Bagi almamater}

Penelitian ini sebagai kontribusi penulis kepada Fakultas Ekonomi Universitas Palembang untuk dijadikan landasan bagi penelitian untuk melakukan penelitian yang sama pada objek lain sehingga memberikan wawasan berpikir yang luas.

\section{TINJAUAN PUSTAKA}

\subsection{Landasan Teori}

\subsubsection{Pengertian Disiplin Kerja}

Pengertian disiplin kerja adalah sebuah konsep dalam organisasi atau manajemen untuk menuntut anggotanya berlaku teratur. Disiplin merupakan keadaan yang menyebabkan atau memberikan dorongan kepada karyawan untuk berbuat dan melakukan segala kegiatan sesuai dengan norma-norma atau aturan-aturan yang telah ditetapkan. Menurut Siagian (2014), pengertian disiplin merupakan tindakan manajemen untuk mendorong para anggota organisasi memenuhi tuntutan berbagai ketentuan tersebut. Dengan perkataan lain, pendisiplinan karyawan adalah suatu bentuk pelatihan yang berusaha memperbaiki dan membentuk pengetahuan, sikap, dan perilaku karyawan sehingga para karyawan tersebut secara sukarela berusaha bekerja secara kooperatif dengan para karyawan yang lain serta meningkatkan prestasi kerjanya. Disiplin kerja adalah suatu alat yang digunakan para manajer untuk berkomunikasi dengan karyawan agar mereka bersedia untuk mengubah suatu perilaku serta sebagai suatu upaya untuk meningkatkan kesadaran dan kesediaan seseorang mentaati semua peraturan perusahaan dan norma-norma sosial yang berlaku (Rivai, 2014). Pengertian disiplin dapat dikonotasikan sebagai suatu hukuman, meskipun arti yang sesungguhnya tidaklah demikian.

Disiplin berasal dari bahasa latin "Disciplina" yang berarti latihan atau pendidikan kesopanan dan kerohanian serta pengembangan tabiat. jadi sifat disiplin berkaitan dengan pengembangan sikap yang layak terhadap pekerjaan. Di dalam buku Wawasan Kerja Aparatur Negara disebutkan bahwa yang dimaksud dengan disiplin adalah "sikap mental yang tercermin dalam perbuatan, tingkah laku perorangan, kelompok atau masyarakat berupa kepatuhan atau ketaatan terhadap peraturan-peraturan yang ditetapkan Pemerintah atau etik, norma serta kaidah yang berlaku dalam masyarakat".Sedangkan menurut Sutopo Yuwono di dalam bukunya yang berjudul Dasar-Dasar Produksi, diungkapkan bahwa disiplin adalah sikap kejiwaan seseorang atau kelompok orang yang senantiasa berkehendak untuk mengikuti atau mematuhi keputusan yang telah ditetapkan. Selanjutnya Alfred R. Lateiner dan I.S. Levine telah memberikan definisi antara lain, disiplin merupakan suatu kekuatan yang selalu berkembang di tubuh para 
pekerja yang membuat mereka dapat mematuhi keputusan dan peraturanperaturan yang telah ditetapkan

Di samping beberapa pengertian mengenai disiplin pegawai tersebut di atas, A.S. Moenir mengemukakan bahwa "Disiplin adalah ketaatan yang sikapnya impersonal, tidak memakai perasan dan tidak memakai perhitungan pamrih atau kepentingan pribadi. Kaitannya dengan kedisiplinan, Astrid S. Susanto juga mengemukakan sesuai dengan keadaan di dalam setiap organisasi, maka disiplin dapat dibedakan menjadi 2 (dua) macam yaitu:

1. Disiplin yang bersifat positif.

2. Disiplin yang bersifat negatif. Merupakan tugas seorang pemimpin untuk mengusahakan terwujudnya suatu disiplin yang mempunyai sifat positif, dengan demikian dapat menghindarkan adanya disiplin yang bersifat negatif. Disiplin positif merupakan suatu hasil pendidikan, kebiasaan atau tradisi dimana seseorang dapat menyesuaikan dirinya dengan keadaan, adapun disiplin negatif sebagai unsur di dalam sikap patuh yang disebabkan oleh adanya perasaan takut akan hukuman. Adapun ukuran tingkat disiplin pegawai menurut I.S. Levine, adalah sebagai berikut: Apabila pegawai datang dengan teratur dan tepat waktu, apabila mereka berpakaian serba baik dan tepat pada pekerjaannya, apabila mereka mempergunakan bahan-bahan dan perlengkapan dengan hati-hati, apabila menghasilkan jumlah dan cara kerja yang ditentukan oleh kantor atau perusahaan, dan selesai pada waktunya. Berdasarkan pada pengertian tersebut di atas, maka tolok ukur pengertian kedisiplinan kerja pegawai adalah sebagai berikut:

1. Kepatuhan terhadap jam-jam kerja.

2. Kepatuhan terhadap instruksi dari atasan, serta pada peraturan dan tata tertib yang berlaku.
3. Berpakaian yang baik pada tempat kerja dan menggunakan tanda pengenal instansi.

4. Menggunakan dan memelihara bahan-bahan dan alat-alat perlengkapan kantor dengan penuh hati-hati.

5. Bekerja dengan mengikuti caracara bekerja yang telah ditentukan.

Selanjutnya untuk lebih

memperjelas arti dan makna displin kerja, Alex S. Nitisemito antara lain mengemukakan, bahwa kedisiplinan lebih dapat diartikan suatu sikap atau perilaku dan perbuatan yang sesuai dengan peraturan-peraturan yang telah ditetapkan oleh perusahaan atau instansi yang bersangkutan baik secara tertulis maupun tidak tertulis. Adapun menurut peraturan disiplin Pegawai Negeri Sipil sebagaimana telah dimuat di dalam Bab II Pasal (2) UU No.43 Tahun 1999, ada beberapa keharusan yang harus dilaksanakan yaitu:

1. Mentaati segala peraturan perundang-undangan dan peraturan kedinasan yang berlaku, serta melaksanakan perintah-perintah kedinasan yang diberikan oleh atasan yang berhak.

2. Melaksanakan tugas dengan sebaikbaiknya serta memberikan pelayanan yang baik terhadap masyarakat sesuai dengan bidang tugasnya.

3. Menggunakan dan memelihara barang-barang dinas dengan sebaikbaiknya.

4. Bersikap dan bertingkah laku sopan santun terhadap masyarakat, sesama Pegawai Negeri Sipil dan atasannya.

Dengan demikian, maka disiplin kerja merupakan praktek secara nyata dari para pegawai terhadap perangkat peraturan yang tedapat dalam suatu organisasi.Dalam hal ini disiplin tidak hanya dalam bentuk ketaatan saja melainkan juga tanggung jawab yang diberikan oleh organisasi, berdasarkan pada hal tersebut diharapkan 
efektifitas pegawai akan meningkat dan bersikap serta bertingkah laku disiplin.

\subsubsection{Pengertian Produktivitas Kerja}

Pada dasarnya produktivitas kerja belum semata-mata diajukan untuk mendapatkan hasil kerja sebanyakbanyaknya, melainkan kualitas kerja juga penting diperhatikan. Produktivitas individu dapat dinilai dari apa yang dilakukan oleh individu yaitu bagaimana seseorang melaksanakan pekerjaannya atau unjuk kerja (job performance).

Dengan demikian produktivitas tidak haya dipandang sebagai perbandingan atau ratio masukan dan keluaran saja melainkan kemampuan seorang karyawan untuk memberikan kontribusi yang positif terhadap lingkungan kerjanya dan mampu mewujudkan sesuatu yang berguna bagi dirinya, penuh ide yang kreatif, berwawasan jauh kedepan dan senantiasa berupaya mencapai tujuan secara efektif dan efisien. Definisi Produktivitas menurut Sinungan (2017) :"Produktivitas kerja adalah hasil (output) yang diperoleh seimbang dengan masukan (input) yang diolah dengan melalui perbaikan cara kerja.Sehingga pemborosan waktu, tenaga dan berbagai input lainnya dapat dikurangi sejauh mungkin dan hasilnya tentu lebih baik dan banyak hal yang dapat dihemat. Yang jelas waktu dipergunakan secara efisien atau tidak terbuang sia-sia dan tenaga dapat digunakan secara efektif. Sehingga pencapaian tujuan usaha atau sasaran yang telah ditetapkan oleh perusahaan dapat terselenggara dengan baik, efektif dan efisien". Dari definisi di atas tampak bahwa produktivitas kerja merupakan perbandingan antara hasil yang diperoleh (output) dengan sumber kerja yang dipergunakan dengan melalui perbaikan cara kerja. Dengan kata lain bahwa produktivitas memiliki dua dimensi. Dimensi pertama adalah efektivitas yang mengarah kepada pencapaian unjuk kerja yang maksimal, pencapaian target yang berkaitan dengan kualitas dan waktu. Yang kedua yaitu efisiensi yang berkaitan dengan upaya membandingkan input dengan realisasi penggunaannya atau bagaimana pekerjaan dilaksanakan.

\subsubsection{Faktor-faktor yang mempengaruhi produktivitas kerja}

Faktor-faktor yang mempengaruhi produktivitas kerja karyawan menurut Simanjuntak (2005) yaitu: 1.Menyangkut kualitas dan kemampuan kondisi karyawan Kualitas dan kemampuan fisik dipengaruhi oleh tingkat pendidikan, latihan, motivasi kerja dari karyawan bersangkutan. Pemupukan motivasi dan sikap kerja yang harus Selalu berorientasi pada produktivitas membutuhkan teknik-teknik tertentu antara lain menciptakan iklim dan lingkungan kerja yang menyenangkan.

\subsection{Penelitian terdahulu}

Untuk mengadakan penelitian, tidak terlepas dari penelitian yang dilakukan oleh peneliti terdahulu dengan tujuan untuk memperkuat hasil dari penelitian yang sedang dilakukan, selain itu juga bertujuan untuk membandingkan dengan penelitian yang dilakukan sebelumnya. Berikut ringkasan hasil penelitian terdahulu yang dilakukan oleh peneliti selama melakukan penelitian

Tabel -1

Ringkasan Hasil Penelitian Terdahulu

\begin{tabular}{|l|l|l|l|l|l|}
\hline No. & Peneliti & \multicolumn{1}{c|}{ Judul } & \multicolumn{1}{c|}{ Variabel } & \multicolumn{1}{c|}{ Hasil } & \multicolumn{1}{c|}{$\begin{array}{c}\text { Alat } \\
\text { Analisis }\end{array}$} \\
\hline 1. & $\begin{array}{l}\text { Naniek } \\
\text { Suryanti } \\
(2007)\end{array}$ & $\begin{array}{l}\text { "Pengaruh Disiplin } \\
\text { dan LoyalitasTerhadap } \\
\text { Kinerja Karyawan } \\
\text { pada CV. Dwi Jaya } \\
\text { Furniture Jepara" }\end{array}$ & $\begin{array}{l}\text { Variabel bebas : } \\
\text { Disiplin (X1) } \\
\text { loyalitas (X2) } \\
\text { Variabel terikat : } \\
\text { kinerja karyawan }\end{array}$ & $\begin{array}{l}\text { Dari hasil uji t test } \\
\text { yang ternyata nilai } \\
\text { koefisien regresi } \\
\text { masing-masing } \\
\text { variabel 4,213;3,201 }\end{array}$ & $\begin{array}{l}\text { Regresi } \\
\text { Linier } \\
\text { berganda }\end{array}$ \\
\hline
\end{tabular}




\begin{tabular}{|c|c|c|c|c|c|}
\hline & & & (Y) & $\begin{array}{l}\text { lebih besar jika } \\
\text { dibandingkan } \\
\text { dengan nilai t table } \\
\text { 1,684, maka t hitung } \\
\text { terletak ditolak (Ho), } \\
\text { artinya hipotesis nihil } \\
\text { (Ho) ditolakdan hipo } \\
\text { tesis alternative (Ha) } \\
\text { diterima. Secara ber } \\
\text { ganda }\end{array}$ & \\
\hline 2. & $\begin{array}{l}\text { Haris } \\
(2009)\end{array}$ & $\begin{array}{l}\text { "Pengaruh Budaya dan } \\
\text { Etos Kerja Terhadap } \\
\text { Kinerja Karyawan } \\
\text { pada PT. WOM Finan } \\
\text { ce Cabang Kudusyang } \\
\text { dilakukan oleh Santoso } \\
\text {, }\end{array}$ & $\begin{array}{l}\text { Variabel bebas : } \\
\text { PengaruhBudaya } \\
\text { (x1) } \\
\text { Etos Kerja (X2) } \\
\text { Variabel terikat : } \\
\text { KinerjaKaryawan } \\
\text { (Y) }\end{array}$ & $\begin{array}{l}\text { bahwa terdapat penga } \\
\text { ruh positif signifikan } \\
\text { lebih kecil dari } 0,05 \text {. } \\
\text { Berdasarkanpenelitian } \\
\text { tersebut dapat dijelas } \\
\text { kan bahwa secara } \\
\text { parsial maupun ber } \\
\text { ganda budaya dan } \\
\text { etos kerja organisasi } \\
\text { sangat menentukan } \\
\text { sikap karyawan dalam } \\
\text { menyelesaikan setiap } \\
\text { pekerjaannya. }\end{array}$ & $\begin{array}{l}\text { Regresi } \\
\text { Linier } \\
\text { berganda }\end{array}$ \\
\hline 3. & $\begin{array}{l}\text { Widdi Ega } \\
\text { Rukmana } \\
\text { (2010) }\end{array}$ & $\begin{array}{l}\text { Analisis Pengaruh } \\
\text { Human Relation } \\
\text { (Hubungan Antar } \\
\text { manusia) dan Kondisi } \\
\text { Fisik Lingkungan } \\
\text { Terhadap Etos Kerja } \\
\text { dan Kinerja Karyawan } \\
\text { Dedy Jaya Plaza Tegal } \\
\text { „ }\end{array}$ & $\begin{array}{l}\text { variabel bebas : } \\
\text { Pengaruh Human } \\
\text { Relation (X1) } \\
\text { Kondisi Fisik } \\
\text { Lingkungan (X2) } \\
\text { Variabel ter ikat } \\
\text { : Etos Kerja dan } \\
\text { Kinerja (Y) }\end{array}$ & $\begin{array}{l}\text { menyimpulkan bahwa } \\
\text { etos kerja terbukti } \\
\text { membawa pengaruh } \\
\text { yang positif dan signi } \\
\text { fikan terhadap kiner } \\
\text { ja. Koefisien penga } \\
\text { ruh etos kerja adalah } \\
\text { sebesar } 0.466 \text { dan } \\
\text { sig.= } 0.002 \text {. Dimana } \\
\text { ini mengindikasikan } \\
\text { bahwa semakin tinggi } \\
\text { etos kerja karyawan } \\
\text { maka dapat mening } \\
\text { katkan kinerja karya } \\
\text { wan tersebut, begitu } \\
\text { pula sebaliknya. }\end{array}$ & $\begin{array}{l}\text { Regresi } \\
\text { Linier } \\
\text { berganda }\end{array}$ \\
\hline
\end{tabular}

\subsection{Kerangka Pikir}

Konsep Kerangka pemikiran adalah istilah dan defenisi yang digunakan untuk menggambarkan secara abstrak mengenai kejadian, keadaan, kelompok atau individu yang menjadi perhatian ilmu sosial. Menurut Singarimbun (2001 : 33), konsep adalah abstraksi mengenai suatu fenomena yang dirumuskan atas dasar generalisasi.

Untuk mendapatkan batasan-batasan yang lebih jelas mengenai variabel-variabel yang akan diteliti, maka defenisi konsep yang digunakan dalam pengertian ini adalah :

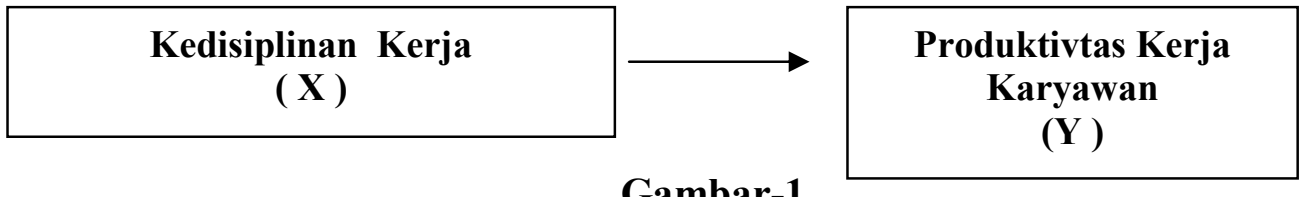

Gambar-1 
Desain penelitian ini menjelaskan hubungan antara variabel (X) dengan variabel $(\mathrm{Y})$, dimana Kedisiplinan Kerja sebagai variabel bebas (X) sangat berpengaruh terhadap Produktivitas Kerja Karyawan sebagai variabel terikat (Y).

\subsection{Hipotesis}

Hipotesisi penelitian ini adalah Ada Pengaruh secara Signifikan Kedisiplinan Kerja Terhadap Produktivitas Kerja Karyawan Pada PT. SBA Wood Industri Palembang.

\section{METODE PENELITIAN}

\subsection{Lokasi Penelitian}

Penelitian ini dilakukan Pada PT. SBA Wood Industri Palembang yang beralamat J1. R.Soekamto Komplek Ruko PTC Blok I No.63-66 Palembang.

\subsection{Ruang Lingkup Penelitian}

Ruang linkup penelitian ini dibatasi dengan Pengaruh Kedisiplinan Kerja Terhadap Produktvitas Kerja Karyawan Pada PT. SBA Wood Industri Palembang

\subsection{Desain Penelitian}

Desain penelitian merupakan pedoman yang digunakan dalam proses penelitian, oleh karena itu perlu disusun desain penelitian yang sistematis untuk menentukan langkah-langkah yang akan dilakukan dalam penelitian. Objek dari penelitian ini adalah "Pengaruh Kesiplinan Kerja Terhadap Produktvitas Kerja Karyawan Pada PT. SBA Wood Industri Palembang”.

Untuk jenis penelitian, yang dipergunakan adalah jenis peneltian studi kasus (case study). Studi kasus adalah jenis penelitian yang dilakukan secara intensif terinci dan mendalam atas suatu proyek penelitian dalam suatu fase spesofik dari keseluruhan personalitas.

Penulis menggunakan jenis penelitian ini dengan alasan bahwa setiap perusahaan mempunyai suatu keadana atau kondisi yang berbeda-beda, hal ini disebabdisebabkan adanya perbedaan besar kecilnya perusahaan dan jenis perusahaan. Pengertian studi kasus dijelaskan oleh Djahidin (2013:66) sebagai berikut : "Studi kasus adalah peneltian tentang status obyek penelitian yang berkenan dengan fase spesifik atau khas dari keeluruhan personalitas. Subyek penelitian dapat saja individu, kelompok, lembaga ataupun masyarakat".

\subsection{Jenis dan Sumber Data}

\subsubsection{Data Primer}

Data Primer yaitu data yang secara langsung berhubungan dengan responden yang diteliti dari sumbenya.

\subsubsection{Data Sekunder}

Data sekunder adalah data yang secara tidak langsung berhubungan dengan responden yang diteliti dan merupakan data pendukung bagi peneliti yang dilakukan. Data sekunder ini biasanya merupakan catatan-catatan yang ada pada perusahaan yang pengumpulannya tidak dilakukan sendiri oleh peneliti.

\subsection{Populasi dan Sampel}

Pada penelitian ini, populasi adalah pekerja dan staff yang bekerja pada PT. SBA Wood Industri Palembang.

Sampel adalah bagian dari jumlah dan karakteristik yang dimiliki oleh populasi tersebut. Sugiyono (2010:116). Adapun penentuan jumlah sampel pada penelitian ini adalah menggunakan teknik probabilitas dengan cara random sampling (Metode sampel acak sederhana), yaitu dengan metode pemilihan sampel di mana setiap anggota populasi mempunyai peluang yang sama untuk dipilih menjadi anggota sampel. Untuk menentukan jumlah sampel yang diambil pada penelitian ini menggunakan rumus slovin : 
Dimana: $\mathrm{n}$ = banyaknya sampel

$$
\mathbf{n}=\frac{n}{N e^{2}+1}
$$

$$
\begin{aligned}
& \mathrm{N}=\text { banyaknya sampel } \\
& \mathrm{e}=\text { persen kelonggaran ketidaktelitian karena kesalahan pengambilan } \\
& \text { sampel yang masih dapat ditolerir, yaitu } 0,1 \text { atau } 10 \% \text {. }
\end{aligned}
$$

Pada penelitian ini yang bertempat pada PT. SBA Wood Industri Palembang. Memiliki karyawan /pekerja sebanyak 350 orang.

$$
\begin{aligned}
\mathrm{n} & =\frac{350}{350 \times 0,1^{2}+1} \\
& =\frac{350}{3,5+1} \\
& =77
\end{aligned}
$$

\begin{tabular}{|c|c|c|c|c|}
\hline No. & Variabel & Definisi & Indikator & $\begin{array}{c}\text { Skala } \\
\text { Pengukuran }\end{array}$ \\
\hline 1. & Disiplin $(X)$ & $\begin{array}{l}\text { Menurut Siagian (2014), } \\
\text { pengertian disiplin merupakan } \\
\text { tindakan manajemen untuk } \\
\text { mendorong para anggota orga } \\
\text { nisasi memenuhi tuntutan berba } \\
\text { gai ketentuan tersebut. }\end{array}$ & $\begin{array}{l}\text { 1. Kepatuhan pada } \\
\text { peraturan } \\
\text { 2. Efektif dalam } \\
\text { bekerja } \\
\text { 3. Tindakan korektif } \\
\text { 4. Kehadiran tepat } \\
\text { waktu } \\
\text { 5. Menyelesaikan } \\
\text { pekerjaan tepat } \\
\text { waktu }\end{array}$ & Likert \\
\hline 2 & $\begin{array}{l}\text { Produktivitas } \\
\text { Karyawan } \\
\text { (Y) }\end{array}$ & $\begin{array}{l}\text { Sukamto (2015), "Produk } \\
\text { tivitas adalah nilai output da } \\
\text { lam hubungan dengan suatu } \\
\text { kesatuan input tertentu. Pening } \\
\text { katan produktivitas yang berarti } \\
\text { jumlah sumber daya yang digu } \\
\text { nakan dengan jumlah barang } \\
\text { dan jasa yang diproduksi se } \\
\text { makin meningkat dan mem } \\
\text { baik". }\end{array}$ & $\begin{array}{l}\text { 1. Kuantitas kerja } \\
\text { 2. Kualitas Kerja } \\
\text { 3. Ketepatan waktu }\end{array}$ & Likert \\
\hline
\end{tabular}

Berdasarkan hasil perhitungan di atas maka penulis menggenapkan jumlah sampel menjadi 78 sampel.

\subsection{Definisi Operasional Variabel}

\section{Tabel-2}

Definisi Variabel

\subsection{Teknik Analisis Data}

a. Uji Validitas dan Reabilitas

Pada setiap pengukuran selalu diharapkan diperoleh hasil ukur yang akurat dan objektif. Salah satu upaya untuk mencapainya adalah alat ukur yang digunakan harus valid atau sahih dan reliabel atau andal (Simamora, Bilson : 2002: 58).

Uji validitas digunakan untuk mendapatkan validitas yang tinggi dari instrumen penelitian sehingga bisa memenuhi persyaratan. Sedangkan uji reliabilitas dilakukan guna memperoleh 
gambaran yang tetap mengenai apa yang diukur. Uji validitas dan reabilitas ini dengan menggunakan koefisien korelasi Pearson Product Moment yang diperoleh melalui analisa data. Item yang memiliki daya beda cukup tinggi akan dihitung reliabilitasnya dengan menggunakan reliabilitas koefisien alpha yang diperoleh melalui analisis data. Item-item dalam skala yang memiliki validitas yang baik dan reliabel akan digunakan untuk mengukur.

b. Analisis Regresi linier Sederhana

Regresi Linear Sederhana

adalah Metode Statistik yang berfungsi untuk menguji sejauh mana hubungan sebab akibat antara Variabel Faktor Penyebab (X) terhadap Variabel Akibatnya. Faktor Penyebab pada umumnya dilambangkan dengan $\mathrm{X}$ atau disebut juga dengan Predictor sedangkan Variabel Akibat dilambangkan dengan $\mathrm{Y}$ atau disebut juga dengan Response.

Regresi Linear Sederhana atau sering disingkat dengan SLR (Simple Linear Regression) juga merupakan salah satu Metode Statistik yang dipergunakan dalam produksi untuk melakukan peramalan ataupun prediksi tentang karakteristik kualitas maupun Kuantitas. Model Persamaan Regresi Linear Sederhana adalah seperti berikut ini :

$$
\mathbf{Y}=\mathbf{a}+\mathbf{b X}
$$

Dimana :

$\mathrm{Y}=$ Variabel Produktivitas Karyawan

(Dependent)

$\mathrm{X}=$ Variabel Kedisiplinan Kerja

(Independent)

$\mathrm{a}=$ konstanta

$\mathrm{b}=$ koefisien regresi (kemiringan); besaran

Response yang ditimbulkan oleh Predictor.

Nilai-nilai a dan $b$ dapat dihitung dengan

menggunakan Rumus dibawah ini :

$$
\begin{aligned}
& \mathrm{a}=\frac{(\Sigma \mathrm{y})\left(\Sigma \mathrm{x}^{2}\right)-(\Sigma \mathrm{x})(\Sigma \mathrm{xy})}{\mathrm{n}\left(\Sigma \mathrm{x}^{2}\right)-(\Sigma \mathrm{x})^{2}} \\
& \dot{\mathrm{b}}=\frac{\mathrm{n}(\Sigma \mathrm{xy})-(\Sigma \mathrm{x})(\Sigma \mathrm{y})}{\mathrm{n}\left(\Sigma \mathrm{x}^{2}\right)-(\Sigma \mathrm{x})^{2}}
\end{aligned}
$$

Data yang diperoleh nantinya akan diolah menggunakan program olah data komputer yaitu SPSS 19.0.0 untuk menghasilakan nilai koefisien determinasi yang lebih akurat.

\subsection{Uji Hipotesis}

\section{- Uji F}

Uji $\mathrm{F}$ digunakan untuk mengetahui pengaruh secara bersama-sama variabel independen terhadap variabel dependen.

- Jika Fitung < Ftabel, maka independen tidak berpengaruh signifikan terhadap variabel dependen.

- $\quad$ Jika Fitung $>$ Ftabel, maka independen mempunyai hubungan yang signifikan terhadap variabel dependen.

\section{- Uji T}

Menurut Sugiono (2010:366), uji T digunakan untuk menguji sendiri-sendiri secara signifikan hubungan antara variabel independen (variabel $\mathrm{X}$ ) dengan variabel dependen (variabel Y).

- Jika thitung $>$ tabel maka variabel independen mempunyai keeratan hubungan yang signifikan terhadap variabel dependen.

- Jika thitung $<$ tabel maka variabel independen tidak mempunyai keeratan hubungan yang signifikan.

\section{HASIL PENELITIAN DAN PEMBAHASAN \\ 4.1 Analisis Data \\ - Uji Validitas}

Menurut Sugiyono (2018:445), instrumen yang valid berarti alat ukur yamg digunakan untuk mendapatkan data (mengukur) itu valid. Teknik yang digunakan untuk mengukur validitas bulir pertanyaan kuisiner adalah correlasion product moment dari Karl Pearson ( Validitas isi / content validity ) dengan cara mengkorelasikan masing-masung item pertanyaan kuesioner dan totalnya , selanjutnya membandingkan $r$ tabel dan $r$ hitung. Pengujian validitas dari penelitian ini dilakukan dengan menggunakan aplikasi sofware SPSS Ver 22,0, jika total (corrected item total corelation) $=0,30$ jadi apabila $\mathrm{r}$ positif 0,3 maka tidak valid. 
Tabe-1

Hasil Uji Validitas

\begin{tabular}{|c|c|c|c|}
\hline Variabel & $\begin{array}{c}\text { Butir } \\
\text { Pertanyaan }\end{array}$ & $\begin{array}{c}\text { Corrected item total } \\
\text { correlation }\end{array}$ & Status \\
\hline \multirow{4}{*}{$\begin{array}{c}\text { Kedisiplinan } \\
\text { Kerja (X) }\end{array}$} & Butir 1 & 0,461 & Valid \\
\cline { 2 - 4 } & Butir 2 & 0,555 & Valid \\
\cline { 2 - 4 } & Butir 3 & 0,458 & Valid \\
\cline { 2 - 4 } & Butir 4 & $\mathbf{0 , 5 7 8}$ & Valid \\
\hline \multirow{2}{*}{$\begin{array}{c}\text { Produktivitas } \\
\text { Kerja } \\
\text { Karyawan } \\
\text { (Y) }\end{array}$} & Butir 5 & 0,443 & Valid \\
\cline { 2 - 4 } & Butir 1 & 0,419 & Valid \\
\cline { 2 - 4 } & Butir 2 3 & 0,532 & Valid \\
\cline { 2 - 4 } & Butir 4 & 0,472 & Valid \\
\hline
\end{tabular}

Sumber : Data diolah 2020

Pada tabel diatas yang menunjukan validasi data penelitian pada variabel bebas dan terikat dapat hasil sebagai berikut :

- Pada variabel Kedisiplinan Kerja (X) bahwa seluruh item dari (5 butir) dinyatakan valid karena Corrected item total correlation menunjukan lebih besar dari > 0,30

- Sedangkan pada variabel Produktivitas Kerja Karyawan (Y) bahwa seluruh item dari (5 butir) dinyatakan valid karena Corrected item total correlation menunjukan lebih besar dari $>0,30$

\section{- Reliabilitas}

Uji reliabilitas dilakukan untuk mengukur tingkat konsistensi antara hasil pengamatan dengan instrumen atau alat ukur yang digunakan pada waktu yang berbrda. Ghozali dalam situmorang (2018: 112) menyatakan teknik yang digunakan untuk mengukur relialitas pengamatan adalah Cronbach Alpha dengan cara membandingkan nilai alpha dengan standarnya, dengan ketentuan :

1. Cronbach Alpha $>0,6$ maka instrumen pengamatan dinyatakan reliabel

2. Cronbach Alpha $<0,6$ maka instrumen pengamatan tidak reliabel

- Reabilitas Variabel Kedisiplinan Kerja (X)

Hasil perhitungan nilai reliabilitas Cronbach Alpa untuk variabel kedisiplinan kerja dengan bantuan SPSS 22,0 adalah sebesar $\mathbf{0 , 5 7 8}$. Artinya dari 5 item pernyataan yang dijadikan sebagai indikator pada variabel kedisiplinan kerja (X) sudah realibel.

- Reabilitas Produktivitas Kerja Karyawan (Y)

Hasil perhitungan nilai reliabilitas Cronbach Alpa untuk variabel kinerja karyawan dengan bantuan SPSS 22,0 adalah sebesar 0,647. Artinya dari 5 item pernyataan yang dijadikan sebagai indikator pada variabel produktivitas (Y) sudah realibel. Hasil uji reabilitas secara lebih terperinci dapat dilihat pada tabel berikut ini : 
Tabel -2

Hasil Uji Reliabilitas

\begin{tabular}{|c|c|c|}
\hline Variabel & Alfha Cronbach ( $\approx)$ & Status \\
\hline Kedisiplinan Karyawan & 0,578 & Reliabilitas \\
\hline Produktivitas Kerja Karyawan & 0,647 & Reliabilitas \\
\hline
\end{tabular}

Tabel -3

Ringkasan Model

\begin{tabular}{|l|r|r|r|r|}
\hline $\begin{array}{l}\text { Mode } \\
1\end{array}$ & $\mathrm{R}$ & R Square & $\begin{array}{c}\text { Adjusted R } \\
\text { Square }\end{array}$ & $\begin{array}{r}\text { Std. Error of } \\
\text { the Estimate }\end{array}$ \\
\hline 1 &, $472^{\mathrm{a}}$ &, 368 &, 058 & 3,55567 \\
\hline
\end{tabular}

a. Predictors: (Constant), Kinerja Karyawan

Sumber : hasil olah data SPSS V 22,0

Koefissien determinasi (R2) pada intinya mengukur seberapa jauh kemampuan model dalam menerangkan variasi variabel dependen. Nilai koefisien determinasi adalah nol atau satu. Nilai R2 = yang kecil bearti kemampuan variabelvariabel independen dalam menjelaskan variasi variabel dependen amat terbatas.

a. $\mathrm{R}$ dalam analisis regresi linier menunjukan korelasi yaitu antara dua variabel independent terhadap satu variabel dependent. Angka R didapat 0 , artinya korelasi antara variabel kedisiplinan kerja dan sebesar 0,472 hal ini bearti terjadi hubungan yang kuat karena nilainya mendekati 1.

b. $\mathrm{R}$ Square $\left(\mathrm{R}^{2}\right)$ yaitu menunjukan nilai koefisien determinasi. Angka ini akan di ubah ke bentuk persen yang artinya persentase sumbangan pengaruh variabel dependent. Nilai $\mathrm{R}^{2}$ sebesar 0,58 artinya sumbangan kedisiplinan kerja terhadap produktivitas kerja karyawan sebesar $42 \%$ sedangkan sisanya dipengaruhi oleh variabel lain yang tidak dimasukkan dalam penelitian ini.

\section{- Uji Regresi linier sederhana}

Data yang diperoleh dari responden dalam penelitian ini dianalisis dengan menggunakan model regresi linier sederhana dengan tujuan untuk mengetahui besarnya kontribusi dari variabel-variabel bebas (independent) dalam peneitian ini yaitu kedisiplinan kerja (X) untuk memprediksi variabel produktivitas kerja karyawan (Y) sebagai variabel terikat (dependent), sehimgga dapat dijelaskan pula mengenai variabel bebas yang paling berpengaruh terhadap variabel terikat nya. Pengelolaan data dilakukan dengan menggunakan program SPSS 22,0 dengan hasil sebagaimana terlihat pada tabel berikut

Tabel -4

\section{Koefisien Regresi}

Coefficients $^{\mathrm{a}}$

\begin{tabular}{|c|c|c|c|c|c|c|}
\hline \multirow{2}{*}{\multicolumn{2}{|c|}{ Model }} & \multicolumn{2}{|c|}{ Unstandardized Coefficients } & Standardized & \multirow[t]{2}{*}{$\mathrm{t}$} & \multirow[t]{2}{*}{ Sig. } \\
\hline & & $B$ & Std. Error & Beta & & \\
\hline \multirow[b]{2}{*}{1} & (Constant) & 18,330 & 6,556 & & 5,468 &, 000 \\
\hline & $\begin{array}{l}\text { Penilaian } \\
\text { Prestasi Kerja }\end{array}$ & ,378 & ,465 &, 060 & 3,248 & ,001 \\
\hline
\end{tabular}

a. Dependent Variable: Produktivitasa Kerja Karyawan

Sumber : hasil olah data SPSS V 22,0 
Tabel dapat dijelaskan sebagai berikut:

Kolom B menunjukan nilai-nilai koefisien regresi untuk konstanta dan masing-masing variabel bebas $\left(\mathrm{X}_{1}\right.$ dan $\mathrm{X}_{2}$ ) kolom (std. Error ) menunjukan nilai kesalahan baku untuk parameter kefisien regresi ,kolom ( beta ) menunjukan besarnya koefisien regresi yang di bakukan atau menunjukan koefsien jalur, kolom ( $t$ ) menunjukan nilai t-hitung untuk masingmasing parameter koefisien kolom ( sig ) menunjukan besarnya peluang kesalahan yang terjadi.

$$
\begin{aligned}
& \mathbf{Y}=\mathbf{a}+\mathbf{b x} \\
& \mathrm{Y}=18,330+0,378 \mathrm{X} \\
& \text { Dimana }: \\
& \mathrm{Y}=\text { Produktivitas Kerja Karyawan } \\
& \mathrm{X}=\text { Kedisiplinan Karyawan } \\
& a \quad=\text { konstanta } \\
& b_{1} b_{2}=\text { koefisien regresi }
\end{aligned}
$$

Memperhatikan persamaan regresi linier sederhana tersebut,diketahui nilai koefisien regresi dari masing-masing variabel bebas yang menunjukkan besarnya nilai yang disumbangkan oleh masing-masing variabel bebas terhadap variabel tidak bebasnya dengan asumsi variabel bebas lainnya dianggap konstan. Nilai koefisien yang mempunyai tanda positif berarti jika variabel bebas meningkat atau ditingkatkan,maka akan mendorong meningkatnya nilai dari variabel tidak bebas,demikian pula sebaliknya.

Penjelasan secara rinci dari masingmasing variabel adalah sebagai berikut:

a. Angka konstanta dari unstandardized coefficient yang dalam penelitian ini sebesar 18,330 angka ini berupa angka konstanta yang mempunyai arti : jika variabel kedisipinan kerja 0,maka jumlah produktivitas kerja karyawan sebesar 18,330

b. Angka koefisien regresi $\mathrm{X}$ sebesar 0,378 . Angka tersebut mempunyai arti bahwa setiap penambahan 1\% kedisiplinan kerja maka produktivitas kerja akan meningkat sebesar $0,378 \%$

\section{Uji secara individu (Uji t)}

Uji t menunjukkan seberapa besar pengaruh variabel bebas yang terdiri dari kedisiplinan kerja (X) mempunyai pengaruh yang signifikan secara individu (parsial) terhadap produktivitas kerja karyawan (Y). Dalam hal ini untuk mengetahui apakah secara parsial variabel kedisiplinan kerja berpengaruh secara signifikan atau tidak terhadap produktivitas kerja karyawan. Pengujian menggunakan tingkat signifikan 0,05 .

\section{Pengujian variabel kedisiplinan kerja (b1) dengan hipotesis : \\ $\mathrm{H} 0=$ koefisien regresi kedisiplinan kerja secara parsial tidak berpengaruh terhadap produktivitas kerja karyawan}

$\mathrm{H} 1=$ koefisien regresi kedisiplinan kerja berpengaruh terhadap produktivitas kerja karyawan

Berdasarkan hasil dari output $t$ hitung diperoleh sebesar 3,248. Untuk mencari $t$ tabel pada signifikan 0,05 dengan derajat kebebasan $\mathrm{df}=\mathrm{n}-\mathrm{k}-1$ atau $77-2-1=74$ maka diperoleh nilai untuk $\mathrm{t}$ tabel sebesar 1,984. Karena t hitung $(3,248)$ $>\mathrm{t}$ tabel $(1,984)$, maka $\mathrm{H} 1$ ditolak,H0 diterima,artinya bahwa kedisiplinan kerja secara parsial ber pengaruh terhadap produktivitas kerja kaaryawan.

\section{Pengujian variabel produktivitas kerja} (b2) dengan hipotesis :

$\begin{array}{rlr}\text { H0 } & =\text { koefisien regresi } \\ & \text { kedisiplinan kerja } & \text { secara } \\ & \text { parsial tidak berpengaruh } \\ & \text { terhadap produktivitas kerja } \\ & \text { karyawan } & \\ \mathrm{H} 1= & \text { koefien regresi kedisiplinan } \\ & \text { kerja secara parsial } \\ & \text { berpengaruh } & \text { terhadap } \\ & \text { produktivitas } & \text { kerja } \\ & \text { karyawan. }\end{array}$


Berdasarkan hasil dari output $\mathrm{t}$ hitung diperoleh sebesar 3,248. Untuk mencari 00,5 dengan derajat komunikasi $\mathrm{df}=\mathrm{n}-\mathrm{k}-1$ atau 77-2-1=74 maka diperoleh nilai untuk $\mathrm{t}$ tabel sebesar 1,984. Karena $\mathrm{t}$ hitung $(3,248)>\mathrm{t}$ tabel $(1,984)$, maka $\mathrm{H} 0$ ditolak, H1 diterima,artinya bahwa kedisiplinan kerja secara parsial berpengaruh terhadap produktivitas kerja karyawan.
- Uji Secara Bersama-sama ( uji f )

Uji-F atau uji koefesien regresi secara bersama-sama digunakan untuk mengetahui apakah secara bersama-sama variabel dependen. Dalam hal ini untuk mengetahui apakah variabel kedisiplinan kerja berpengaruh secara signifikan atau tidak terhadap produktivitas kerja karyawan. Pengujian menggunakan tingkat signifikan

0,05 .

Tabel-5

ANOVA $^{\text {a }}$

\begin{tabular}{|c|c|c|c|c|c|c|}
\hline \multicolumn{2}{|c|}{ Model } & Sum of Squares & Df & Mean Square & $\mathrm{F}$ & Sig. \\
\hline \multirow{3}{*}{1} & Regression & 4,252 & 2 & 3,323 & 65342 &, $000^{5}$ \\
\hline & Residual & 426,333 & 14 & 15,188 & & \\
\hline & Total & 441,458 & 10 & & & \\
\hline
\end{tabular}

a. Dependent Variable: kedisiplinan kerja

b. Predictors: (Constant), produktivitas kerja Karyawan

$\mathrm{H} 0: \mathrm{b} 1, \mathrm{~b} 2=0$, artinya secara bersama-sama tidak terdapat pengaruh yang positif dan signifikan dari variabel bebas $(\mathrm{X})$ yaitu berupa kedisiplinan kerja terhadap produktivitas kerja karyawan sebagai variabel terikat (Y).

$\mathrm{H} 1: \mathrm{b} 1, \mathrm{~b} 2 \neq 0$, artinya secara bersama-sama terdapat pengaruh yang positif dan signifikan dari variabel bebas $(\mathrm{X})$ yaitu berupa kedisiplinan kerja terhadap produktivitas karyawan sebagai variabel terikat (Y).

H0 : Tidak adanya pengaruh kedisiplinan kerja secara parsial terhadap produktivitas kerja karyawan pada kantor PT. SBA Wood Industri Palembang

H0 : Tidak adanya pengaruh kedisiplinan kerja secara bersama-sama terhadap produktivitas kerjakaryawan pada kantor PT. SBA wood industri Palembang

\subsection{Pembahasan}

Berdasarkan hasil analisis data dalam penelitian ini menggunakan metode regresi linier sederhana, dimana variabel-variabel independen yang diduga mempengaruhi mutasi dibatasi satu variabel saja. Variabel yang dianalisis yaitu Produktivitas kerja karyawan. Variabel tersebut dianalisis dengan menggunakan metode analisis regresi linier dengan menggunakan program "SPSS". Tujuan pengujian adalah untuk menguji kebenaran hipotesis variabel tersebut diatas dan melihat bagaimana hubungan dari variabel Produktivitas Kerja Karyawan terhadap Disiplin Kerja. Hasil analisis dengan model regresi linier sederhana terhadap Produktivitas Kerja karyaawan (Y) sebagai dependen dengan variabel Disiplin Kerja (X) sebagai independen variabel, secara lengkap ditampilkan Disiplin Kerja (X) sebagai independen variabel, secara lengkap ditampilkan pada tabel berikut :

Variables Entered/Removed ${ }^{\mathrm{b}}$

\begin{tabular}{|c|c|c|c|}
\hline Model & $\begin{array}{c}\text { Variables } \\
\text { Entered }\end{array}$ & $\begin{array}{c}\text { Variables } \\
\text { Removed }\end{array}$ & Method \\
\hline 1 & Disiplin Kerja $\mathrm{X}^{\mathrm{a}}$ & & Enter \\
\hline
\end{tabular}

a. All requested variables entered

b. Dependenmt Variable : Produktivitas_Y 
Model Summary

\begin{tabular}{|c|r|r|r|r|}
\hline Model & \multicolumn{1}{|c|}{ R } & R Square & $\begin{array}{c}\text { Adjusted R } \\
\text { Square }\end{array}$ & $\begin{array}{c}\text { Std.Error of the } \\
\text { Estimate }\end{array}$ \\
\hline 1 &, $399^{\mathrm{a}}$ &, 340 &, 327 & 7,925 \\
\hline
\end{tabular}

a. Predictors : (Constan), Disiplin Kerja_X

\begin{tabular}{|ll|r|r|r|r|r|}
\hline \multicolumn{7}{|c|}{ ANOVA $^{\text {b }}$} \\
\hline Model & & $\begin{array}{c}\text { Sum of } \\
\text { Squares }\end{array}$ & df & Mean Square & F & Sig. \\
\hline 1 & 194,618 & 1 & 194.618 & 3,099 &, $082^{\mathrm{a}}$ \\
Regression & 4710,369 & 75 & 62,805 & & \\
& Residual & 4904,987 & 76 & & & \\
& Total & & & & & \\
\hline
\end{tabular}

a. Predictors : (Constan), Disiplin Kerja $X$

b. Dependent nVariable: Produktivitas _Y

\section{Coefficients $^{\mathrm{a}}$}

\begin{tabular}{|c|c|c|c|c|c|c|}
\hline Model & & $\begin{array}{r}\text { Understa } \\
\text { Coef }\end{array}$ & $\begin{array}{l}\text { ndardized } \\
\text { icients }\end{array}$ & $\begin{array}{l}\text { Standardized } \\
\text { Coefficients }\end{array}$ & $\mathbf{t}$ & Sig \\
\hline \multirow[b]{2}{*}{1} & & $\mathrm{~B}$ & Std.Error & Beta & \multirow[b]{2}{*}{$\begin{array}{l}7,597 \\
1,760\end{array}$} & \multirow[b]{2}{*}{$\begin{array}{l}, 000 \\
, 082\end{array}$} \\
\hline & $\begin{array}{l}\text { (Constant) } \\
\mathrm{X}\end{array}$ & $\begin{array}{r}50,414 \\
, 187\end{array}$ & $\begin{array}{r}6,636 \\
, 106\end{array}$ & ,199 & & \\
\hline
\end{tabular}

a. Predictors : (Constan), $\mathrm{X}$

b. Dependent : Variable: Y

\section{- Tabel Pada Variables}

\section{Entered/Removed ${ }^{b}$ :}

Menunjukkan variabel apa saja yang diproses, mana yang menjadi vaariabel bebas dan variabel terikat :

Variabel bebas : Disiplin Kerja (X)

Variabeal Terikat : Produktivitas kerja

Karyawan (Y)

\section{- Tabel Model Summary:}

Menampilkan nilai $\mathrm{R}$ yang merupakan simbol dari nilai koefisien korelasi. Pada penelitian diatas nilai korelasi adalah 0,199. Nilai ini dapat diinterprestasikan bahwa hubungan kedua variabel penelitian ada di katogori lemah. Melalui total ini juga diperoleh Nilai $\mathrm{R}$ Square atau koefisien determinasi (KD) yang menunjukkan seberapa besar model regresi yang dibentuk oleh interaksi variabel bebas dan variabel terikat. Nilai KD yang diperoleh adalah $\mathbf{4 0 , 0 \%}$ yang dapat ditafsirkan bahwa variabel bebas $\mathrm{X}$ memiliki pengaruh kontribusi sebesar $40,0 \%$ terhadap variabel $\mathrm{Y}$ dan $60 \%$ lainnya dipengaruhi oleh faktor-faktor lain diluar variabel $\mathrm{X}$.

\section{- Tabel ANOVA}

Digunakan untuk menentukan taraf signifikansi atau linieritas dan regresi, kriterianya dapat ditentukan berdasarkan uji $\mathrm{F}$ atau Uji nilai signifikan (sig). Cara yang paling mudah dengan uji sig dengan ketentuan. Jika nilai signifikan < 0,05 , maka model regresi adalah linier dan berlaku sebaliknya. Berdasarkan tabel diatas diperoleh sig $\mathbf{0 , 0 8 2}$, yang berarti $<$ kriteria signifikan $(0,05)$. Dengan demikian model persamaan regresi berdasarkan data penelitian adalah signifikan, artinya model regresi linier dipengaruhi / memiliki kriteria linieritas. 


\section{- Tabel Cooefficients ${ }^{a}$}

Metode persamaan regresi yang diperoleh dengan koefisien konstanta dan koefisien variabel yang ada di kolom understandarized koefisien B, yaitu :

\section{$\mathrm{Y}=\mathbf{5 0 , 4 1 4}+\mathbf{0 , 1 8 7} \mathrm{X}$}

Persamaan regresi tersebut dapat

dijelaskan sebagai berikut :

a. = 50,414 merupakan nilai konstanta, jika nilai variabel $\mathrm{X}$ adalah nol, maka produktivitas $(\mathrm{Y})$ sebesar 50,414.

$\mathrm{b}_{1}=0,187$ menunjukkan bahwa variabel Disiplin Kerja (X) berpengaruh positif terhadap produktivitas kerja karyawan (Y)

Dengan kata lain jika kepuasan terhadap disiplin kerja ditingkatkan 1 satuan maka produktivitas kerja karyawan akan bertambah sebesar 0,187 satuan skala.

\section{KESIMPULAN DAN SARAN \\ 5.1 Kesimpulan}

1. Pada tingkat pendidikan tingkat pendidikan sebagian besar karyawan PT. SBA Wood Industri Palembang yang menjadi responden dalam penelitian ini adalah SMA yaitu berjumlah 42 orang atau 54,55 persen. Kemudian S1 berjumlah 15 orang atau 19,48 persen dan Diploma berjumlah 20 Orang atau 25,97 persen.

2. Pada Tingkat Usia Responden sebagian besar PT. SBA Wood Industri Palembang yang menjadi responden dalam penelitian ini adalah berusia sekitar 31-40 tahun yaitu berjumlah 32 orang atau 41,56 persen, karyawan yang berusia 21-30 tahun berjumlah 20 orang atau 25,97 persen, karyawan yang berusia 41-50 tahun berjumlah 12 orang atau 15,58 persen. Dan yang paling sedikit adalah karyawan yang berusia 20 tahun yang berjumlah 13 orang atau 16,88 persen.

3. Pada masa kerja sebagian besar karyawan PT.SBA Wood Industri Palembang yang menjadi responden dalam penelitian ini adalah 17 orang atau sebesar 22,08 persen, kaaryawan yang bekerja antara 6-10 tahun berjumlah 20 orang atau 25,98 dan 11-15 tahun adalah masingmasing 25 orang atau 32,46 persen dan karyawan yang masa kerja berkisar 16-20 tahun sebanyak 15 orang atau 19,48 persen.

4. Pada Uji Validitas dapat dilihat bahwa nilai dari $r$ hitung keseluruhan indikator yang diuji bernilai positif dan lebih besar dari nilai $r$ tabel yang besarnya adalah 0,221 . Karena keseluruhan nilai $\mathrm{r}$ hitung semua indikator yang diuji lebih besar daripada nilai $\mathrm{r}$ tabel, maka dapat diambil kesimpulan bahwa semua butir indikator dalam penelitian ini dinyatakan valid.

5. Pada Uji Realibilitas bahwa nilai dari $r$ hitung keseluruhan indikator yang diuji bernilai positif dan lebih besar dari nilai $r$ tabel yang besarnya adalah 0,221. Karena keseluruhan nilai $r$ hitung semua indikator yang diuji lebih besar daripada nilai $r$ tabel, Dimana Nilai Cronbach Alpha Disiplin Kerja (X) adalah 0,597 dan Produktivitas Kerja Karyawan (Y) adalah 0,465 ,maka dapat diambil kesimpulan bahwa semua butir indikator dalam penelitian ini dinyatakan valid.

6. Pada Regresi Linier Sederhana dimana Tabel Model Summary menampilkan nilai $\mathrm{R}$ yang merupakan simbol dari nilai koefisien korelasi. Pada penelitian diatas nilai korelasi adalah $\mathbf{0 , 1 9 9}$. Nilai ini dapat diinterprestasikan bahwa hubungan kedua variabel penelitian ada di katogori lemah. Melalui total ini juga diperoleh Nilai 
R Square atau koefisien determinasi (KD) yang menunjukkan seberapa besar model regresi yang dibentuk oleh interaksi variabel bebas dan variabel terikat. Nilai $\mathrm{KD}$ yang diperoleh adalah 40,0\% yang dapat ditafsirkan bahwa variabel bebas $\mathrm{X}$ memiliki pengaruh kontribusi sebesar $40,0 \%$ terhadap variabel $\mathrm{Y}$ dan $60 \%$ lainnya dipengaruhi oleh faktor-faktor lain diluar variabel $\mathrm{X}$

7. Pada Tabel ANOVA diatas diperoleh sig 0,082, yang berarti $<$ kriteria signifikan $(0,05)$. Dengan demikian model persamaan regresi berdasarkan data penelitian adalah signifikan, artinya model regresi linier dipengaruhi / memiliki kriteria linieritas.

8. Pada Tabel Cooefficients ${ }^{\mathrm{a}}$ Metode persamaan regresi yang diperoleh dengan koefisien konstanta dan koefisien variabel yang ada di kolom understandarized koefisien $\mathrm{B}$, yaitu : $\mathrm{Y}=\mathbf{5 0 , 4 1 4}+\mathbf{0 , 1 8 7} \mathrm{X}$

\subsection{Saran-saran}

1. Sebaiknya pihak kinerja PT. SBA Wood Industri Palembang lebih diintensifkan Hasil dari proses disiplin kerja yang diadakan oleh manajemen perusahaan dapat meningkatkan produktivitas kerja karyawan. Diharapkan dengan adanya kegiatan tersebut menumbuhkan disiplin kerja dari pimpinan dan calon pimpinan dimasa yang akan datang

2. Perlunya kerjasama dengan pihakpihak terkait dalam usaha untuk meningkatkan disiplin kerja dalam meningkatkan produktivitas kerja karyawan untuk bekerja lebih baik lagi.

3. Dari hasil penelitian yang dilakukan, variabel yang paling dominan dalam mempengaruhi produktivitas kerja karyawan yaitu disiplin kerja. Dukungan dari manajer sangat mempengaruhi produktivitaas kerja karyawan. Dukungan lebih yang diberikan oleh manajer dapat membuat karyawan merasa nyaman dalam bekerja dan karyawan diberi tanggungjaawab lebih sehingga karyawan dapat memaksimalkan kemampuannya untuk bekerja lebih baik

4. Untuk penelitian selanjutnya, disarankan untuk menambah variabel bebas yang lain (seperti:Pengetahuan, budaya organisasi,dll). Melakukan penyempurnaan kuesioner, serta melakukan pemilihan waktu yang tepat ketika menyebar kuesioner ini, Hal ini dikarenakan sebagian besar kuesioner dalam penelitian ini tidak dikembalikan.

\section{DAFTAR PUSTAKA}

As'ad, Moh. 2016. Psikologi Industri. Edisi keempat. Liberty Yogyakarta.

Departemen Pendidikan dan Kebudayaan. 2016. Kamus Besar Bahasa Indonesia,Edisi 3. Balai Pustaka Jakarta.

Dharma, Agus. 2017. Manajemen Prestasi Kerja. Edisi Pertama Rajawali, Jakarta.

Gibson, James L., Ivancevich, Donnelly, Jr, 2017. Organisasi: Perilaku, Struktur, Proses. Edisi I. Bina Rupa Aksara, Jakarta.

Hamalik, Oemar. 2015. Psychologi Manajemen. Tri Gendakarya, Bandung.

Handoko, Hani. 2014. Manajemen Personalia. BPFE, Yogyakarta.

Hariandja, Marihot, T.E. 2014. Manajemen Sumber Daya Manusia, Grasindo. Jakarta.

Mangkunegara, A. Prabu. 2016. Evaluasi Kinerja SDM, Refika Aditama, Bandung. 
Mangunhardjana, A.M. 2016.

Mengembangkan Kreativitas,

Terjemahan dari David Cambell.

Kanisius, Jakarta.

Robbins, Stephen. P., 2016. Perilaku Organisasi: Konsep, Kontroversi, Aplikasi. Alih bahasa: Hadyana. Preinhallindo, Jakarta.

Semiawan, Conny, 2014. Memupuk Bakat dan Kreativitas Siswa Sekolah Menengah. Gramedia Jakarta. 